\title{
体積走査型ディスプレイによる立体像と再帰透過光学系を 用いたプロジェクションマッピングの提案
}

\author{
Projection Mapping with 3D Images Using Swept-volume Display and \\ Retro-transmissive Optics
}

清 川真 純 ${ }^{\dagger}$ ，正会員 橋 本 直 己†

Masumi Kiyokawa $^{\dagger}$ and Naoki Hashimoto ${ }^{\dagger}$

\begin{abstract}
あらまし 近年，プロジェクションマッピングは様々な展示やエンターテインメントに用いられるほどに普及し，自由に把持操作 できる物体を対象とした動的プロジェクションマッピングも盛んに研究されている．しかし，従来の動的プロジェクションマッピング では，高度な映像投影を実現するために，プロジェクタやカメラなどの機材が対象を取り囲むように配置されてきた．そのため，操 作するユーザや投映対象自身による遮蔽によって影が生じたり，装置自体が心理的な圧迫感を与えることで，現実感の付与や演出効 果の向上を妨げたりすることが新たな制約となってきた。そこで本論文では，体積走査型ディスプレイによって生成した立体像を光 源として，再䚻透過光学系を用いて投影することで，見えない投影装置によるプロジェクションマッピングを実現する方式を提案す る。この方式を実現する試作機を構築し，プロジェクションマッピングへの利用可能性を検討する.
\end{abstract}

キーワード：空間拡張現実感，プロジェクションマッピング，立体像，体積走査型ディスプレイ，再帰透過光学系

\section{1. ま え がき}

近年，プロジェクタによる映像投影によって実空間に CG 映像を重畳させることで, 実物体があたかも変化したかのよ うに知覚させる空間型拡張現実感技術が，プロジェクション マッピングと呼ばれて一般に普及している. Head Mounted Display 等の映像提示装置の装着を必要としないため, 映像 と現実とのより高い一体感を複数人で同時に体験でき，大 きな映像演出効果を引き出して人々を魅了している．この ような実物体に対するプロジェクションマッピングは，動 かない，即ち静的な対象に対しての投影が一般的であるが， 次世代のプロジェクションマッピングとして，投映対象が 動いたり，人が自由に把持操作できる物体に対して投影する 研究も行われ, 動的プロジェクションマッピング (Dynamic Projection Mapping, DPM) と呼ばれている.これは一部 の展示イベント等1) でも既に活用されている.

しかし DPM では，動く複雑な物体に対して遅れなく映 像を投影することを目指して，投影装置や計測装置の複雑 かつ大規模化が避けられない状況となっている．機材の大 規模化は，その技術の普及の妨げになるだけでなく，体験 者に心理的な圧迫感を与えることにも繋がり，映像演出効 果の最大化を狙う DPM にとっては無視できない損失であ

2021 年 4 月 12 日受付， 2021 年 8 月 13 日再受付， 2021 年 9 月 13 日採録 †電気通信大学 大学院情報理工学研究科

（率 182-8585 東京都調布市調布ヶ丘 1-5-1，TEL 042-443-5345）
るといえる。

そこで本論文では，投影装置を体験者の視野から隠蔽し つつ，動きを伴った物体へのプロジェクションマッピング にも対応可能な投影方式を提案する. 投影装置の隠蔽には, 再帰透過光学系を利用したステルス投影方式2)を採用し， 動く物体の 3 次元形状に対応した光源生成には，体積走査 型ディスプレイを採用する。提案方式に基づいた試作シス テムを実装し，プロジェクションマッピングへの利用可能 性について検討する。

\section{2. 関 連 研 究}

DPM を実現した研究として，Narita ら ${ }^{3)}$ は変形する物 体にマーカを取り付けることで位置姿勢を計測し，その動き に合わせたリアルタイムな映像投影を実現している。マー カを用いない手法としては，Amit ら ${ }^{4)}$ は人の顔を，森久 保ら ${ }^{5)}$ は体験者が把持操作する物体を対象として，その動 きに合わせたリアルタイムな映像投影を実現している。ま た，動的な投影面に焦点を合わせた投影手法として，Wang ら ${ }^{6)}$ は，高速プロジェクタと液体レンズを用いた光学系を 用いて動的な投影面に焦点を合わせる手法を提案している. しかし，物体の位置姿勢，形状の変化を計測するための力 メラ等の機材，そして投影のためのプロジェクタが対象を 取り囲み，体験者の視覚に入ることで DPM の効果を阻害 することが危惧される。加えて，対象物体を把持操作した 際には，投影映像が遮蔽される問題が発生する。

(141) 831 
こうした問題を解決するために，我々は空中像提示技術 を用いたステルス投影 ${ }^{2}$ を提案している. ステルス投影と は，空中像提示技術を応用して遮蔽の影響を除去する投影 法7) と DPM を組み合わせたものであり, 再帰透過光学系 ${ }^{81}$ を介した空中像を投影に用いることで，対象を把持したり するユーザの影を抑えつつ，投影装置を視覚的に隠すこと ができる. ステルス投影では，対象物体と，それに対して面 対称な 3 次元形状をもつ光源を, 再帰透過光学系を挟み込 むように配置する。 そして, 光源からの光線が再帰透過光 学系を介して対称に配置された対象物体表面に再結像する ことで，プロジェクションマッピングが実現される。この 手法に必要な 3 次元光源として, 従来はプロジェクタで投 影されたダミ一物体と呼ばれる実物体を使用していた。し かし，対象物体とダミ一物体は再帰透過光学系に対して面 対称な位置姿勢を常に保ち続ける必要があり, 複雑な同期 機構をダミ一物体側に組み込む必要があった ${ }^{9)}$.

本研究では，複雑な同期機構を排除するために，空間中 に立体的な実像を結像することのできる立体ディスプレイ に着目する．立体像提示手法は広く用いられているが，視 点位置に応じた視差画像を提示する手法 ${ }^{10)}$ では，発光する ダミー物体の置き換えはできない，一方，空間中に光点が 三次元的に配置された状態を作り出すことで，実物体と同 じ形状の立体像を生成する手法 ${ }^{11)}$ であれば，ダミー物体と の置き換えが可能である、レーザ光によって空気をプラズ マ化させる手法 ${ }^{12)}$ は理想的な立体像を生成できるが，プラ ズマ発光を実現する装置が必要になる等，再現が極めて困 難である．また，散乱体へ光を照射することで光点を作り 出す手法では，レーザ損傷で加工されたガラス ${ }^{13)}$ ，液体に 発生させた微細な泡 ${ }^{14)}$, 空間を満たした霧 ${ }^{15)}$ を利用したも のが提案されているが，特殊な散乱体を用意する必要があ る，ライトフィールドを利用する手法备) では，レンズアレ イ等の特殊な光学素子の大手や，複数の光線空間を含んだ 映像の実時間生成が課題となる。

これらに対して，空間中を高速に走査するスクリーンを 散乱体として利用する手法もあり，一般に，体積走査型ディ スプレイと呼ばれている. スクリーンの位置に応じて 3 次 元形状の切断画像を投影することで，各切断画像が視覚的 に統合され，立体像として視認される。 Geng ${ }^{17)}$ は，螺旋型 スクリーンと高速プロジェクタを利用した体積走査型ディ スプレイを提案しており，近年の研究18) でも類似した構成 が提案されている. 3D プリンタを用いることで, 複雑な螺 旋型スクリーンも容易に作成することができ，また，プロ ジェクタ開発キット等を用いることで高速プロジェクタも 容易に利用可能である.

\section{3. 体積走査型ディスプレイを光源に用いたプロジェ クションマッピング}

本研究では，2 節での検討を踏まえ，体積走査型ディス プレイによる 3 次元形状を立体光源として利用した，DPM

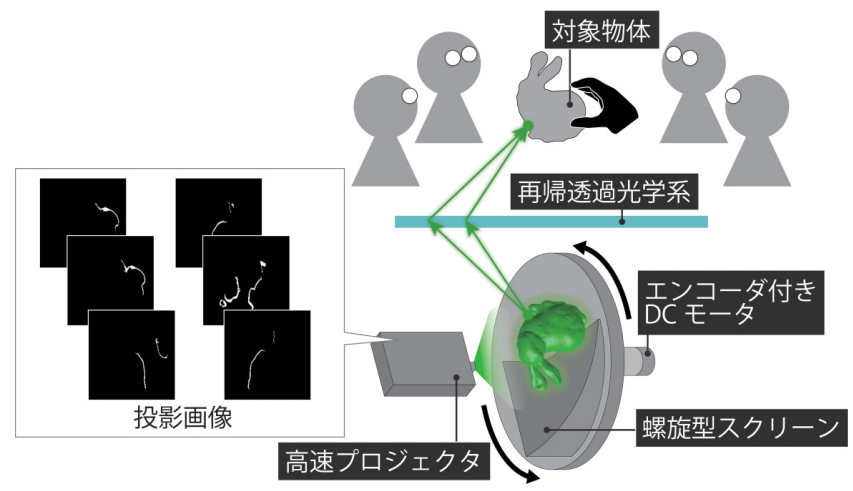

図 1 体積走査型ディスプレイを用いた提案手法の構成

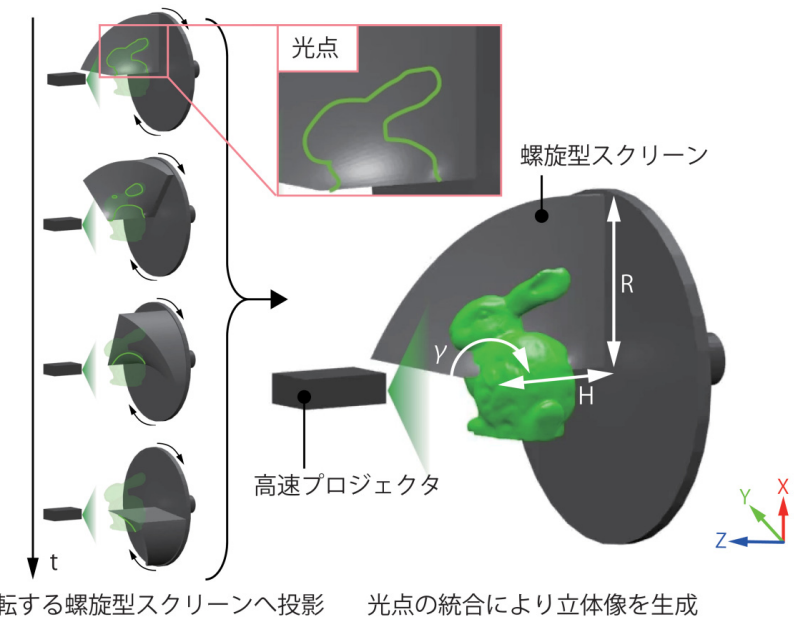

図 2 立体像の生成

にも対応する新たな投影方式を提案する（図 1)。前述のよ うに，ステルス投影には対象物体と同じ形状の光源を必要 とする，本提案では，体積走査型ディスプレイを用いて対 象物体と同じ形状を備え，動きや変形にも対応できる立体 像を作成する．これにより，従来必要であった光源生成用 のダミー物体とその同期機構を取り除くことができ，装置 の簡易化に大きく貢献する.

体積走査型ディスプレイは，3 次元空間内の特定の座標 に光点を形成するため，実物と同じ形状を再現できること が最大の特徴である．ステルス投影において，再帰透過光 学系を介した投影を行うためには，実物体の形状を正確に 再現することが非常に重要である．本研究では，図 1 に示 すように，回転によって空間を走査することで任意の奥行 きを再現できる螺旋型スクリーン（図 2）と，回転するスク リーンに同期して映像を投影するプロジェクタを主な構成 要素としている。一般に，回転しながら回転面に垂直方向 へ移動する曲線を螺旋と呼ぶが，本研究において使用する 螺旋型スクリーンは，ある中心角における螺旋を抽出した 形状となる. 図 2 のように，円周内における螺旋の中心角 $\gamma$ が $\frac{\pi}{2}$ であるとき，スクリーンの表面上の点は式 1 のよう に表される，ただし，スクリーンの回転軸を Z 軸とする.

$$
y=x \tan \gamma, z=\frac{2 H \gamma}{\pi}, \gamma \in\left[0, \frac{\pi}{2}\right], x \in[0, R]
$$




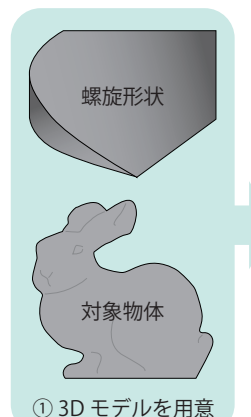

1) 3D モデルを用意

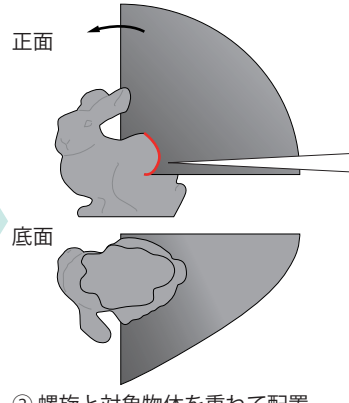

(2) 螺旋と対象物体を重ねて配置

図 3 投影画像の生成方法

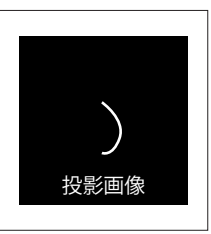

(3) 差分を抽出

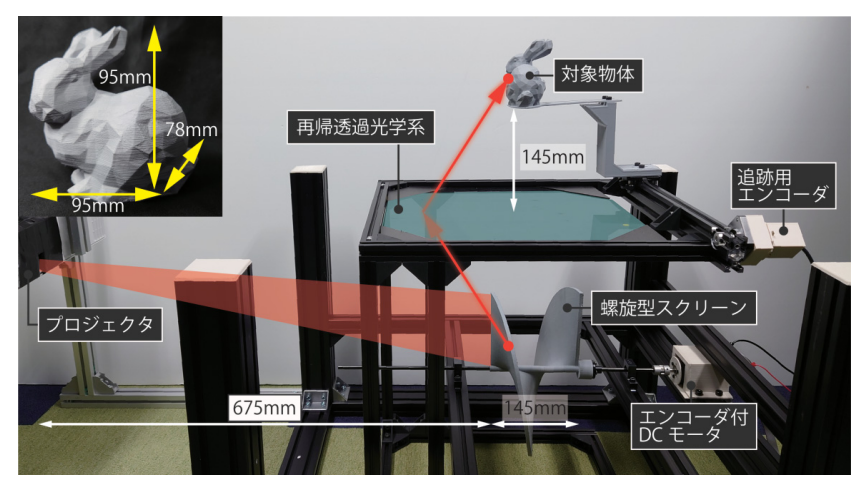

図 4 投影システムの構成 (スクリーンとして図 5 (b) を使用)

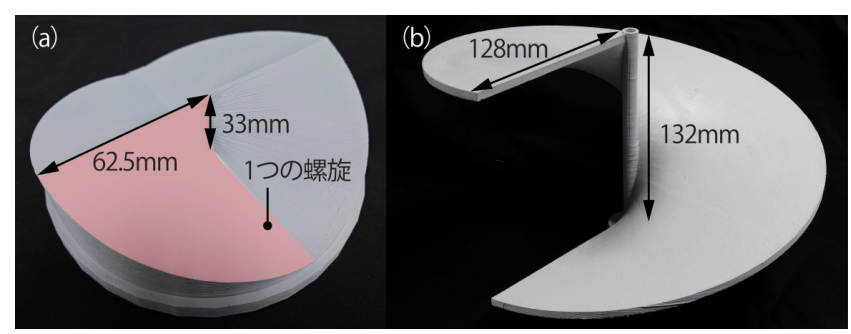

図 5 作成した螺旋型スクリーン：(a) 4 螺旋版 (b) 1 螺旋版

くなる.このため，本研究では下半分に提示した立体像を ステルス投影の光源として使用することは困難である．本 実装では，螺旋型スクリーンの上半分の半円柱状の領域の みに任意の立体像を生成し，立体光源として利用する.

本実装ではスクリーンを 15 回転/秒で回転させ, スクリー ン上の螺旋 4 つを使用するため，立体像のリフレッシュレー トは $60 \mathrm{~Hz}$ となる。これは，映像更新時にちらつきを感じ ない速度を実現している ${ }^{19)}$. 本実装では，螺旋型スクリー ンの回転角が $7.2^{\circ}$ 毎に画像を切り替えるため, スクリーン 1 回転に対して 50 枚の映像が必要となる。そのため，高速 プロジェクタを用いて 750fps の投影を行った．また，映像 を $7.2^{\circ}$ 毎に分割生成することによる不連続感を低減するた めに，回転角 $1.44^{\circ}$ 毎に 5 枚の投影画像生成し，これらを 合成して $7.2^{\circ}$ 分の投影画像を生成した.

\section{2 動的な立体像の生成を行うシステム構成}

本提案手法によって，動いている物体に映像投影を行う DPM を実現するためには，対象の位置姿勢を高速にセン シングし，それに合わせた立体像の投影を行う必要がある. 位置姿勢のセンシングに関しては, 我々が開発した輪郭ベー スの追跡手法 ${ }^{5)}$ を利用することが可能であるが， 4.1 節で 用いた高速プロジェクタは，入手性の高い DLP 開発キッ トを用いたため，プリセットした画像以外を高速に入力す ることが困難であり，また速度を優先させるモードでは単 色での投影に制限される。

そこで本研究では，動的な対象への投影を行う DPM を 実現するために，一般的な更新速度のプロジェクタを使っ た試作システムも用意する。この実装では，一般的なプロ ジェクタの中でも比較的リフレッシュレートの高い，最高 120fps で動作する機種（BenQ: TH685, 1980x1080pixel, 


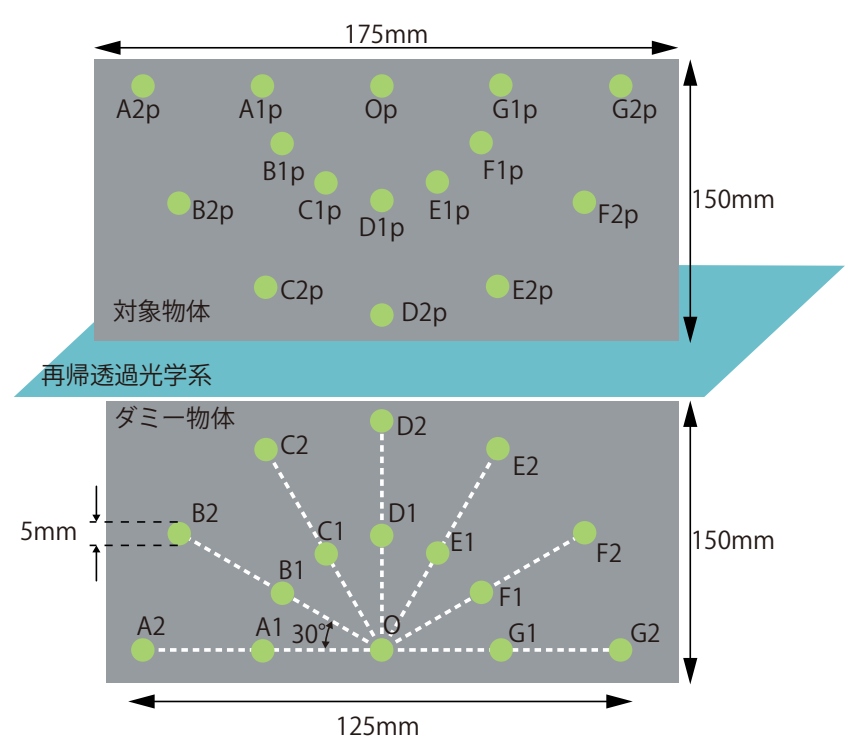

図 6 輝度分布評価における計測箇所

3500lumen）を使用する。一般的なプロジェクタを使用す る場合，リアルタイムな入出力が可能となる一方で，投影 レートが低下し，肉眼で観察することが困難となる．その ため, 動く物体への DPM は, 投影結果を事前に撮影し，才 フライン環境で観察するものとする.

螺旋型スクリーンの形状は，オフラインで評価を実施す ることを踏まえ，リフレッシュレートではなく，奥行き方 向の解像度を優先させた設計とした. 物体の動きに対応で

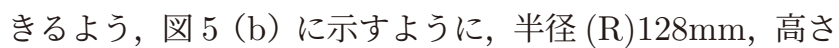
(H)132mm, 円周内の螺旋は 1 つとし，螺旋の谷部分が山 の遮蔽の影響を受けにくい形状としている. 円周内におけ る螺旋の中心角 $\gamma$ は $2 \pi$ となり，スクリーンの表面形状は， 回転軸を Z 軸とした場合に式 2 のように表される.

$$
y=x \tan \gamma, z=\frac{H \gamma}{2 \pi}, \gamma \in[0,2 \pi], x \in[0, R]
$$

この螺旋型スクリーンが安定して回転する最低速度は $60 \mathrm{rpm}$ であり，これにプロジェクタから 100fps で投影を行うこ とで，回転角 $3.6^{\circ}$ 毎に画像を提示し，リフレッシュレート $1 \mathrm{~Hz}$ で立体像を提示した。

本実装では，対象物体の並進位置は，リンク機構で対象 物体に接続されたエンコーダを，また，回転角度は対象物 体に埋め込まれたエンコーダを用いて計測した。計測した 対象物体の位置姿勢に応じた投影画像の生成を，Unity 用いてリアルタイムに実行することで，動的な立体像を生 成した。さらに，スクリーンの回転速度が一定であると仮 定して，映像生成時のスクリーン回転角を調整して，プロ ジェクタの投影遅延を補償した。

\section{5. 評 価 実 験}

本節では，提案手法の映像提示特性やプロジェクション マッピングの実現性について検討を行う。基礎的な評価は, 4.1 節で示した高速プロジェクタを用いた実装を，一方，動
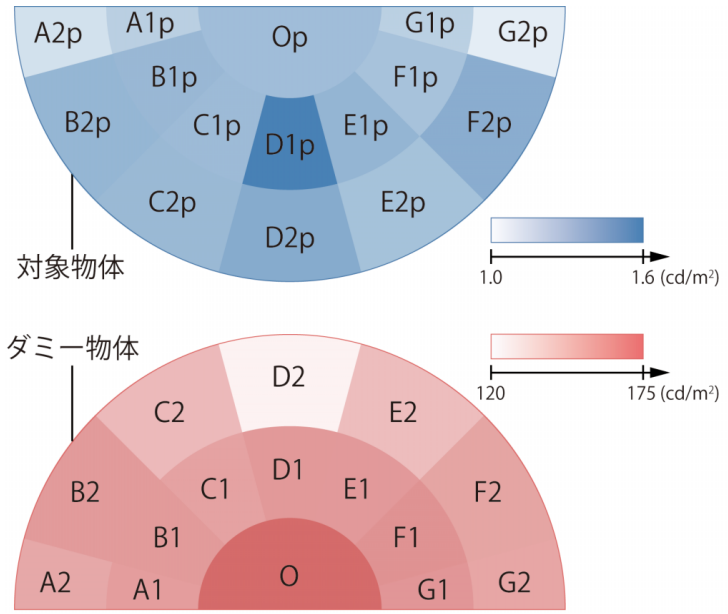

図 7 ダミー物体と対象物体における輝度分布

表 1 ダミー物体と対象物体における輝度計測結果 $\left[\mathrm{cd} / \mathrm{m}^{2}\right]$ (括弧内は分散.ただし $1_{p}$ 及び $2_{p}$ の場合は $\left[\times 10^{-3} \mathrm{~cd} / \mathrm{m}^{2}\right]$ )

\begin{tabular}{r||r|r|r|r|r|r|r|r}
\hline & \multicolumn{1}{c|}{$\mathrm{A}$} & \multicolumn{1}{c|}{$\mathrm{B}$} & \multicolumn{1}{c|}{$\mathrm{C}$} & \multicolumn{1}{c|}{$\mathrm{D}$} & \multicolumn{1}{c|}{$\mathrm{E}$} & \multicolumn{1}{c}{$\mathrm{F}$} & \multicolumn{1}{c}{$\mathrm{G}$} & \multicolumn{1}{c}{$\mathrm{O}$} \\
\hline \hline \multirow{2}{*}{1} & 153.6 & 154.5 & 151.8 & 154.9 & 154.7 & 157.0 & 155.8 & 171.9 \\
& $(5.4)$ & $(4.7)$ & $(1.7)$ & $(2.2)$ & $(3.0)$ & $(9.1)$ & $(4.2)$ & $(6.4)$ \\
\hline \multirow{2}{*}{$1_{p}$} & 1.2 & 1.3 & 1.3 & 1.5 & 1.3 & 1.2 & 1.2 & 1.3 \\
& $(2.0)$ & $(3.6)$ & $(5.3)$ & $(0.7)$ & $(0.3)$ & $(1.2)$ & $(3.7)$ & $(1.8)$ \\
\hline \hline \multirow{2}{*}{2} & 149.9 & 154.3 & 144.1 & 124.3 & 142.9 & 151.3 & 150.7 & \\
& $(2.2)$ & $(6.6)$ & $(3.1)$ & $(2.5)$ & $(1.8)$ & $(8.1)$ & $(7.3)$ & \\
\hline \multirow{2}{*}{2} & 1.1 & 1.3 & 1.3 & 1.3 & 1.3 & 1.3 & 1.1 & \\
& $(1.7)$ & $(5.4)$ & $(0.7)$ & $(4.7)$ & $(5.7)$ & $(8.0)$ & $(10.5)$ &
\end{tabular}

く対象への DPM に関する評価は，4.2 節で示した一般プ ロジェクタを用いた実装を用いる。

\section{1 輝度分布特性の評価}

4.1 節で示した実装において，高速プロジェクタ及び再 帰透過光学系による投影の輝度特性を調査した。ここでは, アクリルに拡散性を高めるための模型用サーフェイサ（ラ イトグレー色）を塗ったプレートをダミー物体，及び対象 物体として用いた. ダミー物体に対し，立体像の提示範囲 を想定した直径 $125 \mathrm{~mm}$ の半円の領域のうち，30ずつ放 射状に配置した 15 箇所（図 6: A[1,2] - G[1,2], O）に，直 径 $5 \mathrm{~mm}$ の円を投影した。 なお，投影箇所 $[\mathrm{A}-\mathrm{G}] 1$ は，対応 する $[\mathrm{A}-\mathrm{G}] 2$ と原点 $\mathrm{O}$ の中点とした.この際，プロジェク タはダミー物体から $420 \mathrm{~mm}$ 離れた位置に，光軸がダミー 物体に対して垂直となるように設置し，ダミ一物体上で投 影像の焦点が合うように調整した。 そして，ダミー物体へ の投影像と，再帰透過光学系を介してステルス投影された 対象物体への投影像（図 6: $\mathrm{A}[1,2]_{p}-\mathrm{G}[1,2]_{p}, \mathrm{O}_{p}$ ）の輝度 を，輝度計 (KONICA MINOLTA: LS-110, 測定輝度範囲 $0.01 \mathrm{~cd} / \mathrm{m}^{2}$ 以上，測定確度 $\pm 2 \%$ ）を用いて 5 回ずつ計測 した。輝度計は計測対象から $500 \mathrm{~mm}$ 離れた位置に，対象 箇所に計測軸が垂直になるように設置した。その平均值と 分散を表 1 に示す。なお，計測時の值のばらつきは，用い た輝度計の計測期間とプロジェクタの輝度制御方式による ものと考えられ，観察時にちらつきなどは特に感じられな かった。

表 1 より，対象物体に投影される輝度が，光源となるダ 
ミー物体上の輝度と比べて約 $1 / 100$ から $1 / 130$ 程度に減衰 することが確認された。これは，より明るいプロジェクタ を使用すると同時に, 再帰透過光学系の面積を広げてより 多くの光を対象物体上に結像させることで，減衰を低減さ せられると考えられる. また，ダミ一物体上の各計測箇所 における輝度值の分布（図 7 下側）では，プロジェクタの 光軸中心に近い $O$ が際立って輝度が高く, 同心円状に輝度 が低下していく傾向が顕著であるのに対し, 再帰透過光学 系を介して投影された対象物体（図 7 上側）では，比較的 均一的な輝度值となっていることが確認された。

これは，ダミー物体側の輝度のばらつきが，ステルス投 影による減衰によって打ち消されたことに加えて, 再帰透 過光学系の特性による影響も考えられる。一般的に, 再帰 透過光学系では, 光源からの距離が増加するにつれて, 光 の減衰や光学系に入射する光の減少によって結像輝度が低 下することが知られている. 表 1 において, 計測点 $[A-G] 1$ に対して $[\mathrm{A}-\mathrm{G}] 2$ は，O から離れているため光源としての 輝度は低下しているが, 対応する $[\mathrm{A}-\mathrm{G}] 1_{p}$ と $[\mathrm{A}-\mathrm{G}] 2_{p}$ を比 較すると，大きな輝度差は確認できない，これは， $[\mathrm{A}-\mathrm{G}] 2$ と $[\mathrm{A}-\mathrm{G}] 2_{p}$ の距離が $[\mathrm{A}-\mathrm{G}] 1$ と $[\mathrm{A}-\mathrm{G}] 1_{p}$ の距離に比べて近 いため, 光源の光がより効率的に投影されたと考えられる.

\section{2 体積型走査ディスプレイによる投影評価}

5.1 節では, ダミー物体を光源として用いたのに対して, ここでは体積型走査ディスプレイを用いて立体像を生成し， 投影を行った状況での評価を行った.

まず，図 5 (a) で示した螺旋型スクリーンが，立体像を提 示可能な直径 $125 \mathrm{~mm}$, 高さ $33 \mathrm{~mm}$ の半円柱状の領域内に おて，映像投影の可否を検証する. 走查領域の上半分のう ち，5.1 節で用いたダミー物体と同じ平面上の 15 箇所（図 8: $\mathrm{A}[1,2]-\mathrm{G}[1,2], \mathrm{O})$ に直径 $5 \mathrm{~mm}$ の円の立体像を提示し た.この層を L1 とし（図 8)，10mm 間隔で奥行きをずら した L2，L3についても，それぞれ 15 箇所へ円形の像を提 示した．また，プロジェクタから $\mathrm{L} 1$ までの距離を $420 \mathrm{~mm}$ とした. 各層に立体像を提示した際の上側対称位置を基準 位置とし，その基準位置，及びそこから前後に $10 \mathrm{~mm}$ ずら した位置にアクリル製プレートを配置した際の，投影像の 中心輝度を計測した結果を図 9 に示す。計測は, 対称性を 考慮して, 中央を含んだ左半分の 9 䇢所 $\left(\mathrm{A}[1,2]_{p}-\mathrm{D}[1,2]_{p}\right.$, $\left.\mathrm{O}_{p}\right)$ で行い， 1 箇所につき 5 回ずつ計測した平均值を示し ている.

図 9 より，L1，L2，L3 それぞれの 9 箇所の像いずれに おいても，基準点の時に輝度がピーク值となることが確認 できた.これは，基準点において光が最も強く集まるとい う再帰透過光学系の特性が正しく機能していることの表れ であり，立体像を生成した対称位置に，像を投影すること ができることを示唆している.

次に, 立体的な対象物体に対して, プロジェクションマッ ピングを試みた。ここでは，3D プリンタで作成したサイ ズ $85 \mathrm{~mm} \times 60 \mathrm{~mm} \times 80 \mathrm{~mm}$ の Stanford Bunny に, 緑色

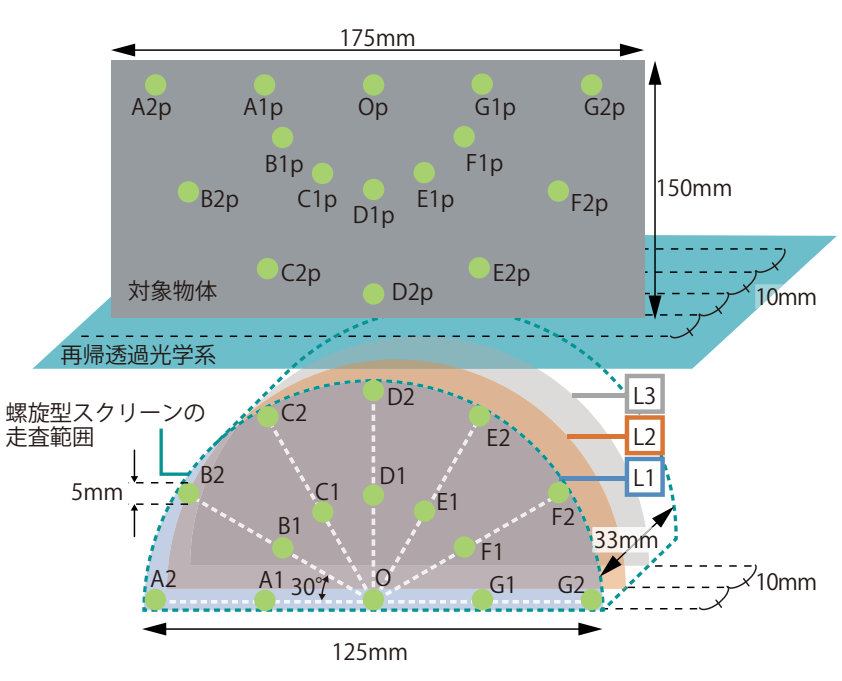

図 8 体積型ディスプレイを用いた投影評価の計測箇所
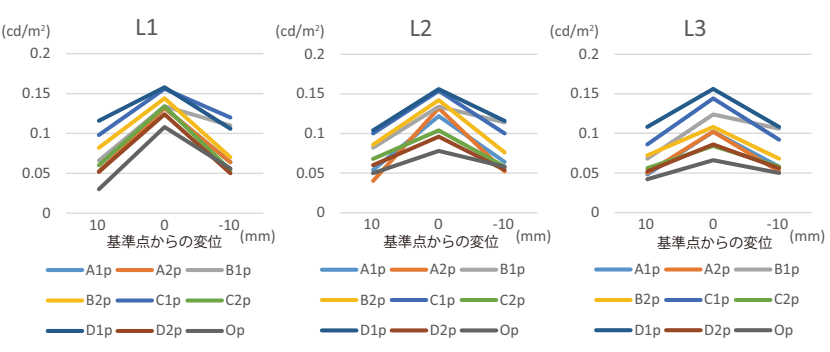

図 9 投映対象の位置における輝度計測結果

の単色縞模様のテクスチャを表示することを目標とした. まず，通常のプロジェクタによる直接投影を想定して，体 積走査型ディスプレイを用いて平面状の光源を生成した場 合（図 10 (a)）と，提案手法の特徴である，対象物体の 3 次元形状を再現したの光源を用いた場合（図 10（b）及び （c））を比較した（b）では，投影された映像の見やすさを 優先して, 対象物体の側面が観察方向に向くょうに配置し た. 一方，(c) では，(b) の対象物体を中心縦軸に対して $33^{\circ}$ 回転させることで，奥行き方向により幅広く対象物体 を配置し，異なる奥行きに対する映像投影の様子を確認で きるようにした，その結果，対象形状を再現した光源を用 いた場合には，対象物の全範囲において縦縞模様を確認す ることができた，平面状に結像する投影象では，投映対象 と形状が一致しないため，充分に焦点のあった投影が実現 できなかったと考えられる．また，図 10 (c) と同姿勢の対 象物体に対して，ダミー物体を使ってステルス投影を行っ た場合（図 $10(d))$ と比較しても，提案手法では同程度の 縦縞模様が再現されていることが確認できた.

以上の結果より，ステルス投影方式に体積走査型ディス プレイを光源として組み合わせることで，3次元形状を有 する投映対象にダミー物体を用いたときと同程度の投影を 実現できることが示された.

\section{3 動的な対象への投影における印象評価}

これまでの評価で用いてきた試作システムでは，すで述 べたとおり，DPM への対応が困難である，そこで，本提 

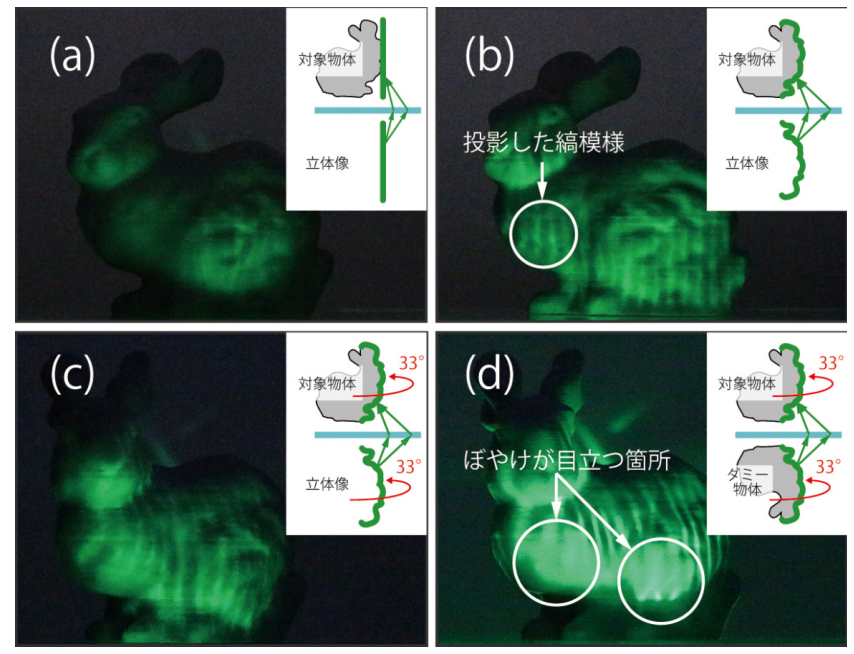

図 10 異なる光源再現による投影の比較：(a) 平面状，(b) 対 象形状，(c) 対象形状 (33 回転)，(d) 対象形状 (ダ ミ一物体)

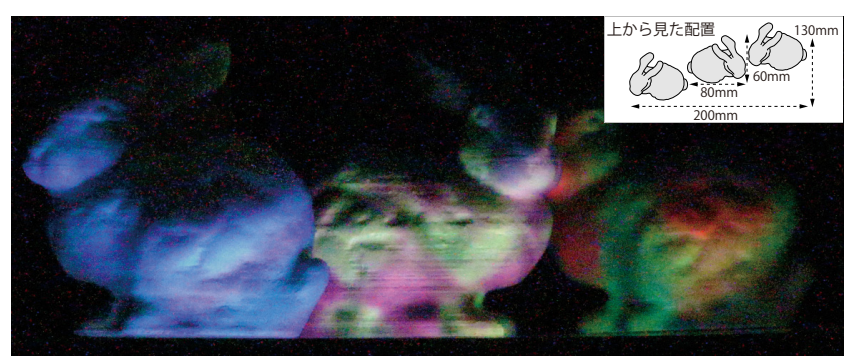

図 11 複数の対象物体への投影の様子

案手法を用いて動く物体に対するDPM を行った際の印象 やステルス投影の効果を評価するために，本実験では 4.2 節で示した一般プロジェクタを用いた実装を用いた。螺旋 型スクリーンは, 図 5 （b）に示した 1 螺旋構成のものを用 いた. 動く物体に対応した広い立体像提示領域を実現可能 であり, 図 11 に示すように，複数の Stanford Bunny を 配置した状態でも，全てに映像投影が可能であった。

一般的なプロジェクタを使用したステルス投影では，前 述の通り，リフレッシュレートが低いため，目視での投影 の確認が困難である。そこで，対象物体をわずかに動かし ながら撮影したコマ撮りの写真を使用して 30fps のストッ プモーション動画を作成し，オンラインフォームを利用し たアンケート形式による印象評価を行った。動画では投影 対象として Stanford Bunny を用い，15cm の距離を 1 秒 で左右に往復し続ける並進動画と，物体の中心縦軸に対し $\tau \pm 120^{\circ} / \mathrm{s}$ の回転を 1 秒毎交互に繰り返す回転動画を作成 した．回転動画の一部を図 12 に示す.

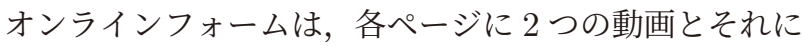
対して一対比較を行う質問を掲載し, 結果を回答した後に, 次のページへ遷移する形式とした．まず，10 代から 20 代 の男女 8 人の被験者に対し, 物体の動き（並進と回転）毎 に，投影を行わずに物体を動かした様子と，投影して動か した様子の動画を提示し，どちらが映像を投影したものだ と感じたかと質問した。 その結果，並進では 8 人中 7 人,

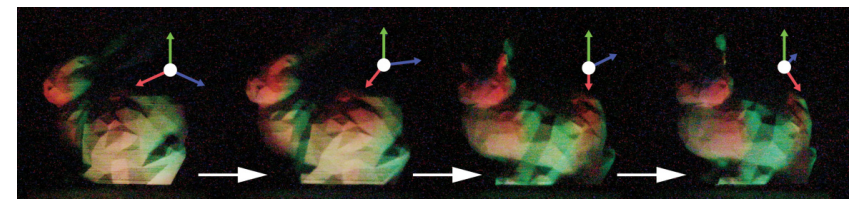

図 12 対象物体を回転させた際の投影の様子

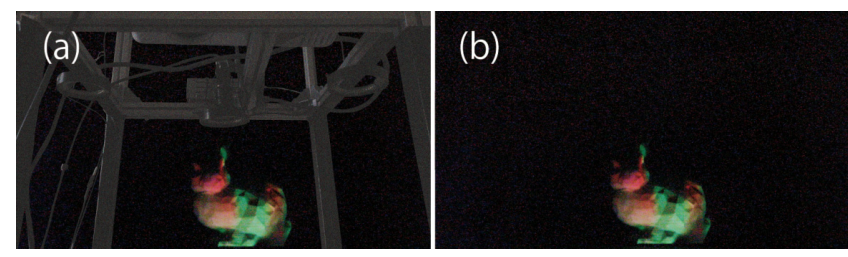

図 13 （a）従来の投影環境，（b）提案手法の投影環境

回転では 8 人全員が後者を選択したことから，プロジェク ションマッピングが実現できていることが確認できた。ま た，並進で投影を確認できた 7 人のうち，物体の移動に対 して物体表面の模様が追従しているょうに見えたと回答し たのは 6 人であり，また，回転で投影を確認できた 8 人に おいては 7 人であった。 さらにその映像が魅力的に感じた と回答したのは並進では 6 人中 5 人，回転では 7 人全員で あった．魅力を感じた要因としては，投影機材が見えない ことから見栄えが良く，使用用途が広がる等の意見が自由 記述欄から確認できた。

次に，先のアンケートにおいて投影機材が見えないこと が好印象につながったという意見が寄せられたことにも関 連して，DPMに打いて投影装置を視覚的に隠蔽するステ ルス投影の効果を検証するために，前述と同様に，提案手 法によって DPM を実現した動画と，上方に投影装置を備 えた通常の DPM 環境5) を重畳表示することで再現した動 画から，好みの環境を被験者に選択させた（図 13)。先の 評価と同じ 8 人の被験者から回答を得た結果，並進では 8 人中 7 人が，回転では 6 人が，投影装置が隠蔽された提案 手法による環境を選択した。自由記述欄において，投影装 置の存在を好意的に捉える被験者もいたが，多くはその圧 迫感を嫌う傾向がみられ，ステルス投影がプロジェクショ ンマッピングの価值を高める可能性が示唆された.

以上の結果より，今回の評価は限定された環境での実施 となったが，提案手法によって観察者が魅力的だと感じら れるDPM が実現されることが確認できた.

\section{6. むす び}

本論文では，体積走査型ディスプレイによる立体像を光 源として, 再帰透過光学系を用いて投影機材を視覚的に噯蔽 しつつ，動く物体への DPM にも対応したプロジェクショ ンマッピングを実現する新しい投影方式を提案した.

試作システムを用いた評価を通して，投影映像の品質や 提示範囲については改善の余地があるものの，従来システ ムにはないプロジェクションマッピングに適した投影特性 を実現することで，より魅力的な映像提示の実現可能性を 
示すことができた。より高性能な高速プロジェクタが実現 の要になるが，すでに商品化も進んでおり，今後は本提案 手法の実現性もより向上していくと考えられる. プロジェ クタの制約が改善された状況において，リアルタイム動作 する DPM を実現し，投映対象とユーザの対話を含んだ映 像投影に関しても評価を行っていきたい。また，投映対象 の位置姿勢計測にカメラを使った非接触方式を組み合わる ことで，より自然なプロジェクションマッピングを実現し たい，さらに，本論文で示した実装では，投影対象の上側 に映像を投影することが困難であるため，体積走査型ディ スプレイを上方に配置して下向きに投影する構成や，投影 対象を中空かつ半透明化して，下方に置かれたディスプレ イからの投影を可能にする方法 ${ }^{20)}$ 等についても検討してい きたい.

本研究は JSPS 科研費 JP19H04152 の助成を受けた.

\section{〔文献〕}

1）Panasonic 株式会社, “特集 アスリートの動きに追従する巧み な映像演出 スポーツメテクノロジーがもたらす新時代の体験価 值": "https://news.panasonic.com/jp/stories/2019/71648.html", (参照日 2021/4/9)

2) M. Kiyokawa, S. Okuda and N. Hashimoto: "Stealth Projection: Visually Removing Projectors from Dynamic Projection Mapping", SA '19 ACM SIGGRAPH Asia 2019 Posters, 41 (2019)

3) G. Narita, Y. Watanabe, and M. Ishikawa: "Dynamic Projection Mapping onto Deforming Non-rigid Surface using Deformable Dot Cluster Marker", IEEE Transactions on Visualization and Computer Graphics, 23, 3, pp. 1235-1248 (2017)

4) Amit H. Bermano, M. Billeter, D. Iwai, and A. Grundhofer: "Makeup Lamps: Live Augmentation of Human Faces via Projection", Computer Graphics Forum, 36, 2, pp. 311-323 (2017)

5）森久保優輝, 橋本直己: “Dynamic Projection Mapping のための輪郭 に基づく反復計算によるロバストな位置姿勢推定”, 第 24 回日本バー チャルリアリティ学会大会, 5C-08 (2019)

6) L. Wang, H. Xu, and S. Tabata, Y. Hu, Yunpu, Y. Watanabe and M. Ishikawa: "High-Speed Focal Tracking Projection Based on Liquid Lens", SIGGRAPH '20 ACM SIGGRAPH 2020 Emerging Technologies (2020)

7) K. Hiratani, D. Iwai, P. Punpongsanon and K. Sato: "Shadowless Projector: Suppressing Shadows in Projection Mapping with Micro Mirror Array Plate", 2019 IEEE Conference on Virtual Reality and 3D User Interfaces (VR), pp. 1309-1310 (2019)

8) O. Makoto: "Optical imaging apparatus and optical imaging method using the same", U.S. Patent No. 8,702,252. Washington, DC: U.S. Patent and Trademark Office (2014)

9）清川真純, 橋本直己: “ステルスプロジェクションにおける投影物体との 同期機構に関する検討”, 映像情報メディア学会 冬季大会 $2019,12 \mathrm{C}-7$ (2019)

10) A. Jones, I. McDowall, H. Yamada, M. Bolas, and P. Debevec: "Rendering for an Interactive $360^{\circ}$ Light Field Display", SIGGRAPH '07 ACM SIGGRAPH 2007 Papers (2007)

11）宮崎大介: “特集: 裸眼立体表示技術 5 章 体積表示方式”, 映像情報又 ディア学会誌, 68, 11, pp. 844-849 (2014)

12) Y. Ochiai, K. Kumagai, T. Hoshi, J. Rekimoto, S. Hasegawa, and Y. Hayasaki: "Fairy Lights in Femtoseconds: Aerial and Volumetric Graphics Rendered by Focused Femtosecond Laser Combined with Computational Holographic Fields", ACM Transactions on Graphics (TOG), 35, 2, pp. 17:1-17:14 (2016)

13) Shree K. Nayar and Vijay N. Anand: "3D Volumetric Display Using Passive Optical Scatterers", SIGGRAPH '06 ACM SIGGRAPH 2006 Sketches (2006)

14) K. Kumagai, T. Chiba and Y. Hayasaki: "Volumetric bubble display with a gold-nanoparticle-containing glycerin screen", Opt. Express, 23, pp. 33911-33920 (2020)

15) W. Yamada, H. Manabe, D. Ikeda and J. Rekimoto: "RayGraphy: Aerial Volumetric Graphics Rendered Using Lasers in Fog", Symposium on Spatial User Interaction, 11 (2020)

16) N. Okaichi, M. Kawakita, H. Sasaki, H. Watanabe, and T.
Mishina: "High - quality direct - view display combining multiple integral 3D images", Society for Information Display, 27, 1, pp. 41-52 (2018)

17) J. Geng: "A volumetric 3D display based on a DLP projection engine", Displays, 34, 1, pp. 39-48 (2013)

18) R. Asahina, T. Nomoto, T. Yoshida and Y. Watanabe: "Realistic Volumetric 3D Display Using Physical Materials", SA '20 ACM SIGGRAPH Asia 2020 Emerging Technologies, 10 (2020)

19) S. Hecht and S. Shlaer: "Intermittent stimulation by light: V. the relation between intensity and critical frequency for different parts of the spectrum", The Journal of General Physiology, 19, 6, pp. 965-977 (1936)

20）奥田慎一，橋本直己: “前面投影と背面投影の組み合わせによるステ ルス投影の広域化”, 映像情報メディア学会技術報告, $4 \mathbf{4 4}, 4$, pp. 19-22 (2020)

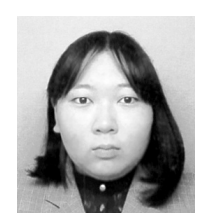

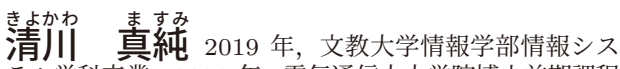
厂么学科卒業. 2021 年, 電気通信大大学院博士前期課程 (情報学専攻) 修了. 映像投影技術㳊関する研究经從事. 修士 (工学).

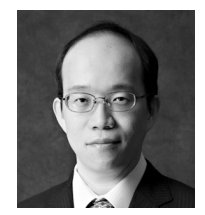

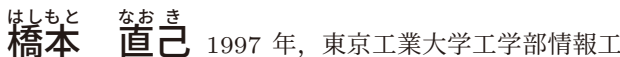
学科卒業. 1999 年, 同大学院博士前期課程 (計算工学専 攻) 修了. 2001 年, 同大学院博士後期課程 (計算工学専 攻) 修了. 同年, 同大精密工学研究所助手. 2007 年, 同 研究所助教. 2008 年, 電気通信大学情報工学科准教授, 2010 年, 同大学総合情報学専攻准教授, 2020 年, 同大 学情報学専攻教授, 現在に至る. バーチャルリアリティ, 没入型ディスプレイ, 映像投影技術に関する研究に従事. 博士 (工学). 正会員. 